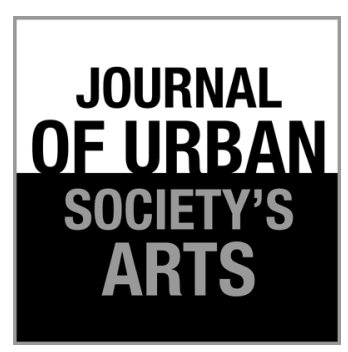

Volume 6 Nomor 2,

Oktober 2019: 87-100

\section{Losing the Battle: Questioning the Hegemony of Postcolonial Aesthetics in the Representation of Illustration Pictures at Taman Pintar Yogyakarta}

\author{
Kasiyan
}

Department of Fine Arts Education

Faculty of Languages and Arts

Universitas Negeri Yogyakarta

Jalan Colombo No. 1 Karangmalang, Yogyakarta 55281

HP. 08122753970,E-mail: kasiyan@uny.ac.id

\begin{abstract}
ABSTRAK
Kekalahan Pertempuran: Mempersoalkan Hegemoni Estetika Postkolonial dalam Representasi Gambar Ilustrasi di Taman Pintar Yogyakarta. Artikel ini mendeskripsikan hegemoni estetika postkolonial yang terepresentasikan melalui gambar ilustrasi yang ada di salah satu tempat wisata edukasi di Yogyakarta, yakni Taman Pintar, beserta faktor penyebabnya. Penelitian ini menggunakan pendekatan hermeneutik, dengan instrumen utamanya adalah peneliti sendiri sebagai human instrument. Sementara itu teknik analisisnya dengan deskriptif kualitatif. Hasil penelitian ini dapat disampaikan sebagai berikut. Pertama, bentuk hegemoni estetika postkolonial dalam gambar ilustrasi di Taman Pintar Yogyakarta, tampak dari penggunaan dan sekaligus pengedepanan atau penonjolan sosok para tokoh penemu ilmu pengetahuan modern, yang semuanya berasal dari Barat, dan tidak ada satu pun tokoh yang berasal dari Timur. Hal ini menghasilkan konstruksi wacana yang bias hegemoni Barat sentris. Fenomena itu adalah sebentuk kekalahan pertempuran dalam kontestasi kebudayaan, yang sejatinya sama sekali tak boleh ditransformasikan dan diinternalisasikan kepada anak didik yang akan menjadi generasi pewaris dan sekaligus penerus masa depan. Kedua, terkait dengan fenomena hegemoni Barat tersebut disebabkan terutama oleh masih kuatnya beban sindrom postkolonialisme yang dihadapi oleh bangsa Indonesia meskipun sudah berada di era kemerdekaan.
\end{abstract}

Kata kunci: hegemoni estetika postkolonial; gambar ilustrasi; Taman Pintar Yogyakarta

\begin{abstract}
This article describes the hegemony of postcolonial aesthetics, which is represented in illustration pictures in one of he educational tourist attractions in Yogyakarta, namely Taman Pintar, along with its causes. This study used a hermeneutic approach, with the researcher himself was as the main instrument. The analysis technique used was descriptive qualitative. The results of the analysis revealed some points. Firstly, the form of postcolonial aesthetic hegemony in illustration pictures of Taman Pintar was manifested by the use of images of the inventors of modern science. All of the inventors came from the West, and none of them came from the East. It resulted in the construction of discourse with a Western bias. This phenomenon is a kind of losing the battle in the cultural constellation that is not supposed to be transformed and internalized to young generation who will be the next generation of this country in the future. Secondly, this phenomenon of Western hegemony is caused mainly by the existence of the significant burden of Western post-colonialism syndrome faced by this nation, Indonesia.
\end{abstract}

Keywords: hegemony; postcolonial aesthetics; illustration pictures; Taman Pintar Yogyakarta 


\section{Introduction}

Edu-park or educational park can be considered as a new form of tourist attractions that nowadays becoming one of the society's favorites. This kind of tourist attraction is actually combining the concepts of tourism and education that is well known as educational tourism or edu-tourism (Matahir \& Tang, 2017; Novelli \& Burns, 2010; Ritchie, Carr, \& Cooper, 2003). The concept of education in this edu-tourism context is closely related with the domain of non formal education as noted by Patterson (2017:163), that "Educational tourism lies somewhere in the middle and has been described as non-formal learning".

The existence of educational park as one part of edu-tourism is believed to have positive value not only in terms of knowledge or specific skill enrichment but also values and cultural attitude development that are important and needed by the society (Greene, Kisida, \& Daniel, 2014), or as mentioned by Matthews \& Boyns (2001) as the ability to serve as a kind of abstract "hyperspace", "imagistical", and meaningful power. It is for those reasons that "edu-tourism" has been developed in various parts of world, such as Malaysia (Matahir \& Tang, 2017; Yekinni \& Yusof, 2015; Mura \& Tavakoli, 2014), Philipines (Magnaye, 2019), Taiwan (Obrien \& Jamnia, 2013.), China (Bai, Cai, \& Zhang, 1999), and many other countries not to mention Indonesia.

In Indonesian context, this edu-tourism phenomenon can be found for instance in Yogyakarta and also in almost all of its big cities, such as Bali (Clendinning, 2016), Jakarta (Martin \& Endangsih, 2018; Andisca, Harsasto, \& Adnan, 2016), Solo (Priyanti, Suparno, \& Sumaryoto, 2019), Semarang (Priasani, 2009), Purwokerto (Kodri, Indriastjario, \& Dwiyanto, 2013), Mataram (Rahman, Singgih, \& Setyaningsih, 2014), and many others.

This variety of edu-tourism existing in the society is commonly formatted as theme park (Aziz \& Ariffin, 2012; Zhang \& Shan, 2016), that is a place designed with a specific theme, for instance, science, adventure, futurism, international/world landmark, nature, waterpark, and history and culture (Lukas, 2008). In Indonesia, there has been a government rule concerning the management of edu-tourism mentioned in Government Act Number 10 Year 2009, Article No. 17, subsection 2 G, about Conducting Entertainment and Recreation Activity particularly Thematic Park Business.

Having the form of theme park, this type of edu-tourism is intended to be visited mainly by children starting from the age of before school to high school, that is commonly done in the form of a school activity known as study tour or field trip, that is commonly defined as a trip or visit done by students for the sake of education or to learn a particular thing (Greene, Kisida, \& Bowen, 2015). One of the advantages of conducting an educational activity in the form of field trip for students is, it can be not only as a pleasure study as it is conducted together with recreation (Tan Yigitcanlar, 2013; Durado \& Leite, 2013; Merritt, Kline, Crawford, Viren, \& Dilworth, 2016), but also it provides various learning experinces that are more authentic-factual compared to the one conducted in the classroom (Caron \& Carr-Hill, 1991; Zepke \& Leach, 2006; Wong \& Wong, 2009a, b; Latchem, 2014).

In Yogyakarta's context, the edu-tourism is called Taman Pintar located in the centre of Yogyakarta municipality, particularly on Panembahan Senopati Street Number 1-3 which is in the same area of some tourist destinations such as Benteng Vredeburg, Taman Budaya, Societiet Militer, and Gedung Agung. This edu-tourism combines the concepts of tourism or recreation and education as mentioned in its slogan, "Taman Pintar, Wahana Ilmu Pengetahuan", (Taman Pintar, A place for Science) and also "Taman Pintar, Mencerdaskan dan Menyenangkan" (Taman Pintar, a place for making people smart and fun) (http://www.tamanpintar. com). Having the 1,2 hectare in wide, Taman Pintar Yogyakarta is one of the government ideas to facilitate the society's great interest in sciences. The establishment of this edu-tourism in Yogyakarta is also influenced by its slogan as students' town. Officially opened for public on December $16^{\text {th }}$, 2008, Taman Pintar Yogyakarta has become the most favorite place to visit with the highest number 
of visitor compared to other tourism objects in Yogyakarta. As an illustration, from 2009 to 2018, the number of people visiting this edu-park reaches one million every year (https://jogjapolitan. harianjogja.com/read/2018/12/29/510/961857/ pengunjung-taman-pintar-tembus-1-juta-orang).

Taman Pintar Yogyakarta has a number of playground and educational areas that are divided into various zones, for instance, Playground, PAUD, Memorabilia, Planetarium, and many others with the total of 54 zones completed by more than 3.500 educational toy media (http://www.tempo. $\mathrm{co} / \mathrm{read} /$ news $/ 2012 / 05 / 13 / 199403585 /$ TamanPintar-Yogyakarta-Dilengkapi-Wahana-Air, Tempo Interaktif, retrieved in March 2017). One of the most visited zones is the science zone that is located in Oval-Kotak Building. Visitors could find many visual aids of educational sciences (http://jogja. tribunnews.com/2017/07/05/wahana-teknologiinformasi-paling-diminati-pengunjung-tamanpintar).

The main underlying question that becomes the focus of this study is the fact that in this science zone of Taman Pintar Yogyakarta, there are pictures or illustration pictures of world philosophers, the founders of world sciences that are interesting to be discussed. These illustration pictures in this context are functioned as the media to provide clear educative information for children (Onwuekwe, 2012:1; Toor, 1996:31) whose development age are in the stage of being not yet capable to think of abstract things (McCleneghan \& Jackson, 2019:9). For this stage, the existence of a picture is worth one thousand words (Thoo, 1998; Hittleman, 2012). The illustration pictures of those science inventors are very aesthetically displayed at Taman Pintar Yogyakarta, in one of its most strategic rooms that is at the front part of the first floor of Oval-Kotak Building, particularly on the wall next to the round stairs connecting the first to the second floor. The basic problem of the existence of these illustration pictures of world science inventors is the fact that all of them are from the West and not even one inventor or expert is from Eastern countries. Some of them are Nicolaus Copernicus, Sir Francis Bacon, Rene Descartes, Sir Issac Newton, Albert Einstein, and many others.
Meanwhile based on the existing historical facts, it is clearly noted that not all of the founders of world modern science and technology are from the West. Many of them are from the East. Even there were many East great advancements of science and technology together with their products of technology far before those from the West. These facts can be easily verified from the history of the appearance of East philosophy and science that has appeared before the one of the West or it can be considered as older than that of the West (Syam, 2009:75). Eastern philosophy and science, mainly those developed in the Middle East has appeared since 6000 BC (Richard, 2010; Rochberg, 2017), in di Egypt and around Tigris and Eufrat rivers starting in $5000 \mathrm{BC}$, in Palestina in aroundd in 4000 BC, in India and China around 3000 BC (Syam, 2009:75). Meanwhile, the philosophy and science tradition considered as the oldest in Europe (Greek and Rome) were started to be known around 650 BC (Syam, 2009:75; Sacks \& Murray, 1995:87; Howatson, 2013:109).

Indeed, various great advancements of science and technology historically were started from the East although in later development, some of them are consciously denied in modern sciences that tend to be biased as the results of Western hegemony.

Therefore, the phenomenon of the history of science inventions that are very biased of Western hegemony as represented in those of illustration pictures/images at Taman Pintar Yogyakarta can be considered not merely as a kind of historical manipulation but at the same time also as a condition of "losing the battle" experienced culturally by Eastern nations, not to mention Indonesia. This phenomenon implies the appearance of inferiority complex spirits on Eastern nations as being under Western colonialization in the past that they tend to consider Western people superior.

This phenomenon is what Said (1979) mentioned as the postcolonial syndrome that is full of colonial mentality simptom (Decena, 2014; Belton, 2014; Rafael, 2015). One thing to be noted is that if this postcolonial problem is internalized to children who are still in the golden period of development (Bryant, 2011; Atwood \&Stolorow, 
2013), it will create more destructive impact towards their personality in the future.

Seen from the aesthetic point of view, the phenomenon of illustration pictures in the form of science inventors with Western bias is considered as estheticism, a kind of art works, whose value substances have been lost from truth messages and values (Whewell, 2009: 128-130), that they tend to have negative or even destructive and tragic meaning (Odin, 2016: 81; Comfort, 2008: 140).

This representation model of illustration pictures as a part of estheticism art works is naturally called an aesthetic work, which is anti-aesthetic (Foster, 2002; Madoff, 2009; Croce \& Ainslie, 1995). If we refer back to substance of aesthetics from its early history that it never separates the terminology of "beauty", "truth" and "goodness", as mentioned by Sahakian (1963: 64), that, "The aesthetic soul, who loves truth and pursues the good".

Regarding this background, the study of the construction of postcolonial aesthetics hegemony in the illustration picture representation at Taman Pintar Yogyakarta is very important, strategic and urgent to be conducted. Owing to the fact that Taman Pintar Yogyakarta, as mentioned earlier, is one of edu-tourism destinations for children, every kind of science representations not to mention those presented through illustration pictures in Taman Pintar Yogyakarta will play significant roles not only in terms of the Indonesian children's science development but in terms of the existence of entity and identity of Eastern and particularly Indonesian values in the future.

In relation to that, this study focuses on two main questions, i.e. to discuss the manifestation of postcolonial aesthetic hegemony represented at illustration pictures in Taman Pintar Yogyakarta and to describe factors leading this hegemony.

The main method used in this study is naturalistic method (Lapan, Quartaroli, \& Riemer, 2011), with hermeneutic approach that focuses on activities on making interpretations (Laverty, 2003). The main instrument is the researcher himself (Brown \& Baker, 2007: 71). Then, the data analysis technique used is descriptive qualitative particularly the interactive model proposed by Miles, Huberman, \& Saldaña (2013).

\section{The Manifestation of Postcolonial Aesthetic Hegemony Represented at Illustration Pictures in Taman Pintar Yogyakarta}

The representation of postcolonial aesthetic hegemony in illustration pictures in Taman Pintar Yogyakarta can be identified at Oval-Kotak Building that serves as the science zone, an area to learn sciences, particularly natural sciences. The illustration works found are in the form of pictures of the inventors of modern science inventors coming from the West. The illustration pictures of those important people in the advancement of modern science are placed or displayed in the main room next to the entrance area containing a big aquarium with a collection of scarce fish and an area of ancient culture and life. This main room used to display those illustration pictures can be said to be the most strategic one. It is located in the first floor and it is designed similar to the design of the main lobby. This room is also the largest one that those illustration pictures are clearly seen and dominantly fill the room.

The illustration pictures are displayed on the wall of that room that is on the right side of the round stairs, the one connecting the room with the upper room. It implies that all of the modern sciences display existing in the entire second floor and the other floors of the building are mainly based on

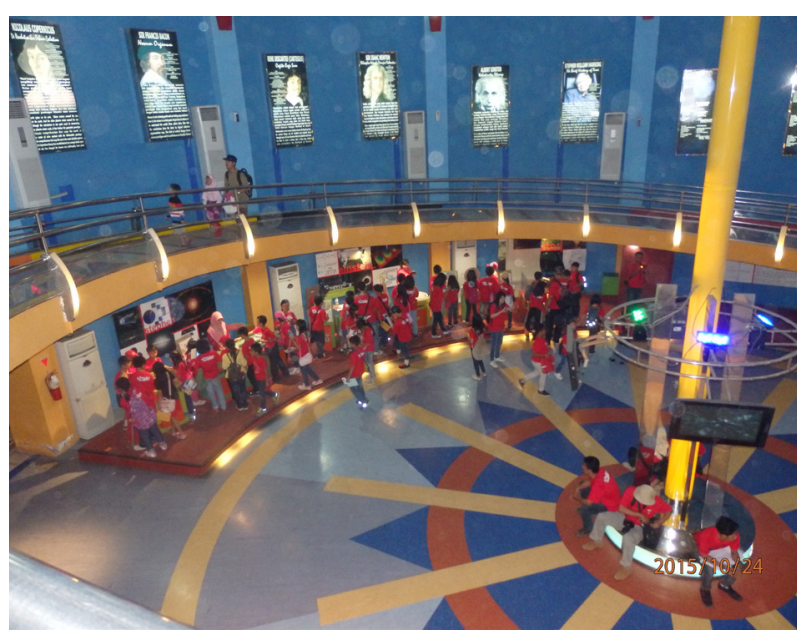

Figure 1. The Display of the Illustration Pictures on the wall of the Main Room of Oval-Kotak Building at Taman Pintar Yogyakarta. (Source: A Photo by Kasiyan) 
the inventions of theories done by those of science inventors whose figures displayed in the first floor. The following is a figure showing the display of the illustration pictures of the Oval-Kotak Building in Taman Pintar Yogyakarta.

Figure 1 shows the display of 6 Western scientist, namely Stephen William Hawking, Albert Einstein, Sir Issac Newton, René Descartes, Sir Francis Bacon, and Nicolaus Copernicus. Each picture displays the figure of each scientist in the middle of the display accompanied by a certain note. The note includes four things. The first is the identity name of the scientist written in capital letters with the biggest size and placed on top of the picture. The second note is about the identity of the great theory the scientist has found. This note is placed underneath the scientist's name. The third note is a brief biography of the scientist covering the place and date of his birth and death, and the reason why the person becomes famous. This note is placed in the left side of the pictures and written with a relatively smaller letters. Meanwhile, the forth note is the text about the substance of the theory he/she has found, which is written in a bi-lingual (English and Indonesian language) text and placed underneath the scientist's

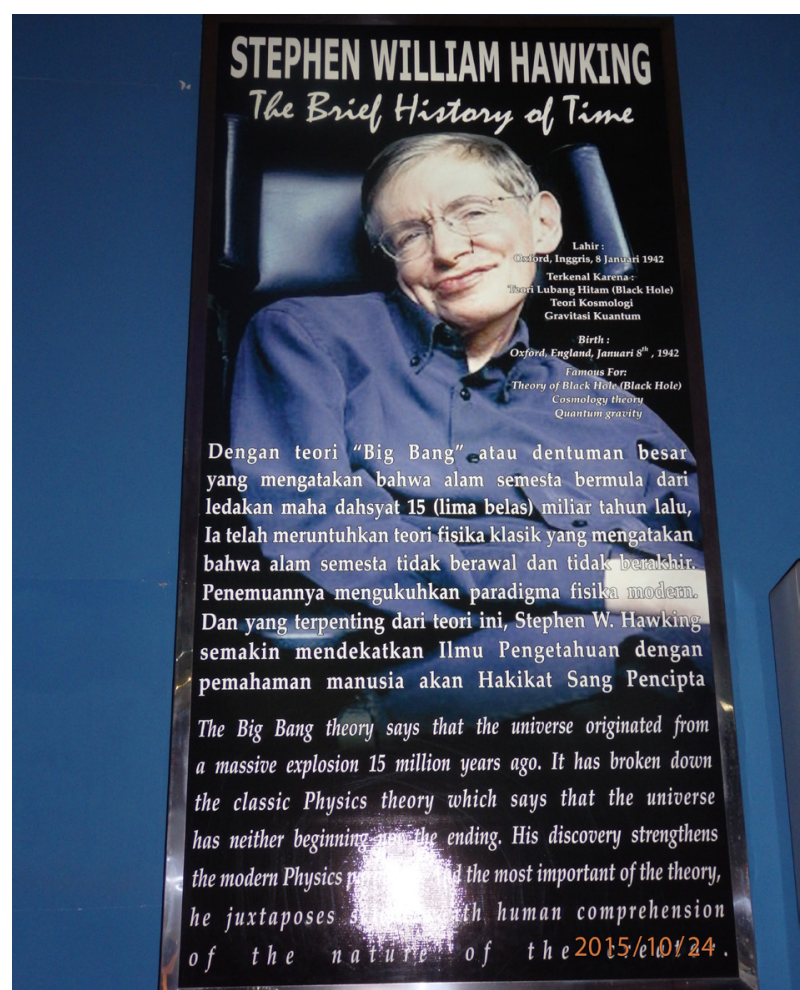

Figure 2. The Illustration Picture of Stephen William Hawking in the Main Room of Oval-Kotak Building at Taman Pintar Yogyakarta. (Source: A Photo by Kasiyan) picture taking the half page of the display plane. The following is the display of the postcolonial aesthetic hegemony represented in illustration pictures at Taman Pintar Yogyakarta as mentioned earlier.

Figure 2 shows the figure of Stephen W. Hawking, as on of well-known Western scientists. It is seen that under the picture of the scientist, there is a note underneath his name saying that "The Brief History of Time". On the right side of the picture, there is a note about his birthday in Oxford, England, on January $8^{\text {th }}, 1942$. There is also a brief narration of what has made him a famous person that is because of the black hole theory, cosmology theory and quantum gravity theory. Beside the picture, it is written a rather longer sentence saying that: "The Big Bang theory or the big bang says that the universe originated from a massive explosion 15 (fifteen) million years ago. It has broken down the classic Physics theory which says that that the universe has neither beginning nor ending." His discovery strengthens the modern Physic paradigm. One of the most important things about Hawkings' theory is the fact that it has made science to get closer to the humans' understanding about the nature of the Creator.

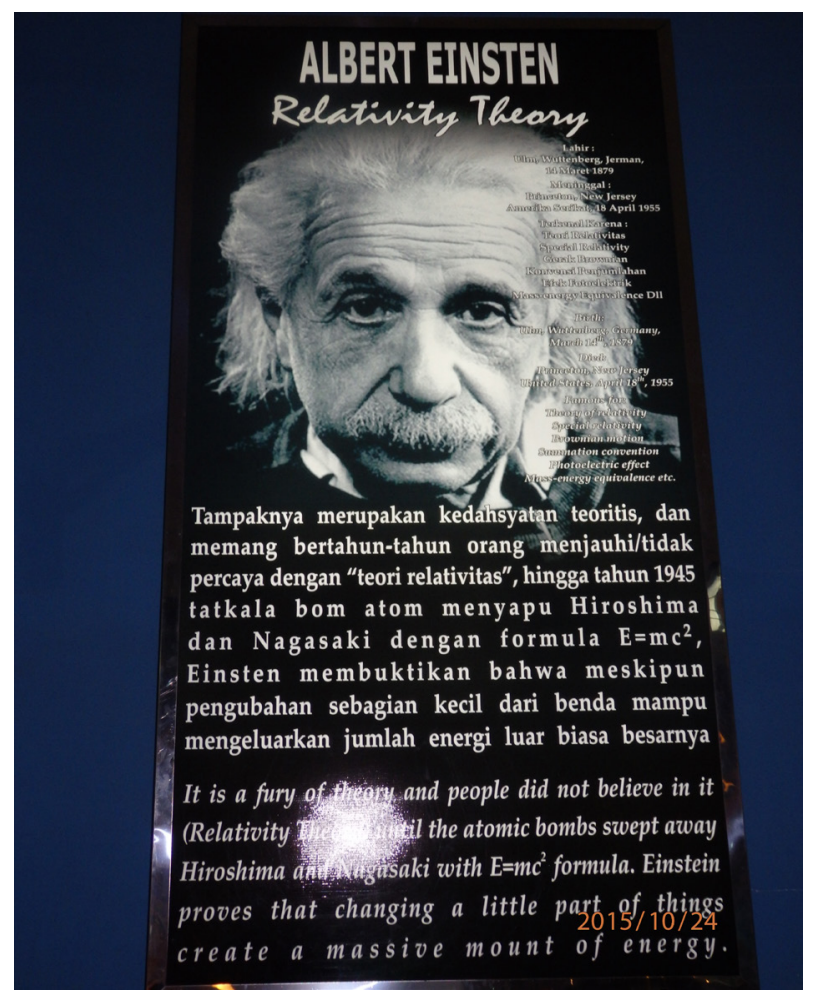

Figure 3. The Illustration Picture of Albert Einstein in the Main Room of Oval-Kotak Building at Taman Pintar Yogyakarta. (Source: A Photo by Kasiyan) 
Figure 3 shows the figure of Albert Einstein. Underneath his name which is written on the very top of the illustration picture, it is written Relativity Theory, as his finding. On the right side of his picture, a brief biography of his the scientist is written, covering the information that he was born in Württemberg, Germany on March $14^{\text {th }}, 1879$ and died in the United States on April 18 $8^{\text {th }}, 1955$. Then, in the middle of the illustration, there is a text saying "It is fury theory and people did not believe in it (Relativity Theory) until the atomic bombs swept away Hiroshima and Nagaski with $\mathrm{E}=\mathrm{mc}^{2}$ formula. Einstein proves that changing a little part of thungs create a massive mount of energy".

Figure 4 shows the figure of Sir Isaac Newton. Underneath the illustration picture, there is a note saying Philosophia Naturalis Principia Mathematica. It is actually his book published in 1687 and is considered as the most influential book throughout the history of science. There is also a brief note about him. It is written that he was born in Woolsthorpe England on December 25 $5^{\text {th }}, 1642$ and died in Kensington, London, England on March $20^{\text {th }}$, 1727. It is also mentioned the reason why he

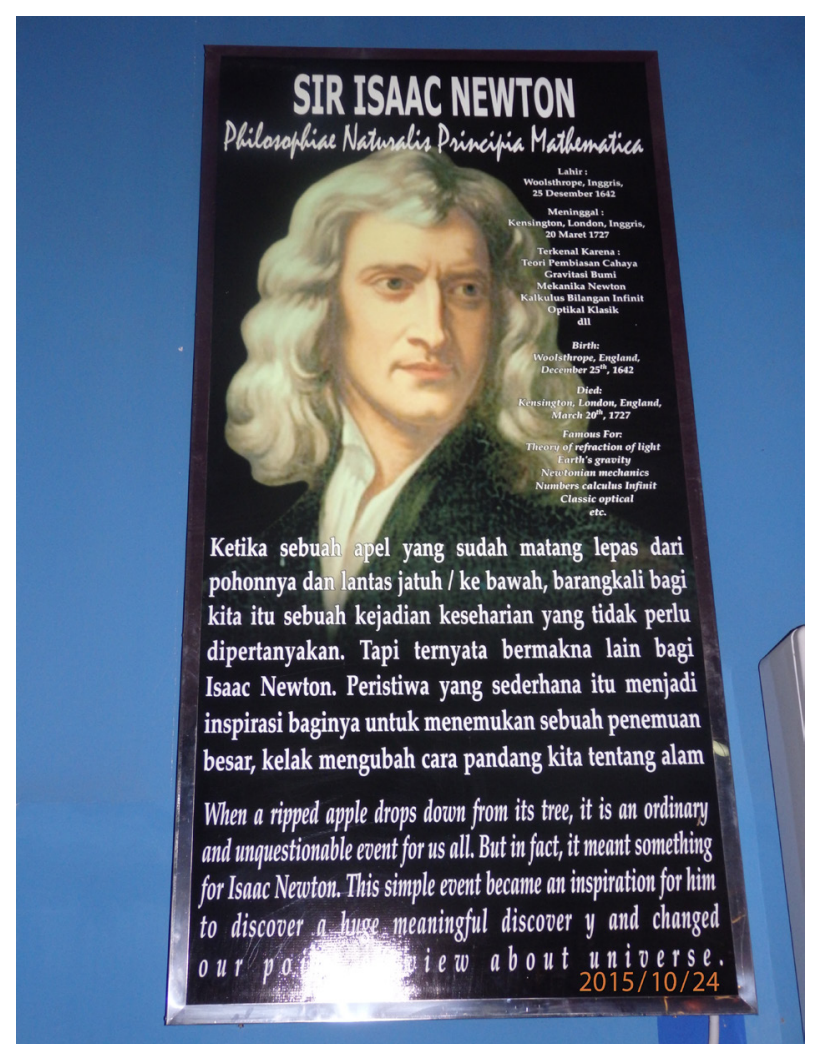

Figure 4. The Illustration Picture of Sir Issac Newton in the Main Room of Oval-Kotak Building at Taman Pintar Yogyakarta. (Source: A Photo by Kasiyan) became famous. It is written that he is wellknown for his theories of light refraction, earth gravitation, Newton mechanics, infinitive number calculus, classical optic, and many other. On the other part it is written a longer text saying, "When aripped apple down from its tree, it is an ordinary and unquestionable event for us all. But in fact, it meant something for Isaac Newton. The simple event became an inspiration for him to discover a huge meaningful doscovery and changed our point of view about universe".

Figure 5 shows the figure of René Descartes (Cartesius), and underneath his name, it is written a short note of Cogito Ergo Sum. Then, there is an additional note talking about his brief biography. It is written that he was born in La Haye, Perancis, on March 31, 1596 and died in Stockholm, Sweden, on February 1650. It is written that he is known as the Father of Modern Philosophy, the Father of Modern Math, Methods of doubt, Cartesian coordinate. There is a summary of his theory saying that, "Mathematics is the essence of pure reason. He theorizes that the correct could be verified and tracked down though sense. He suggested that is to

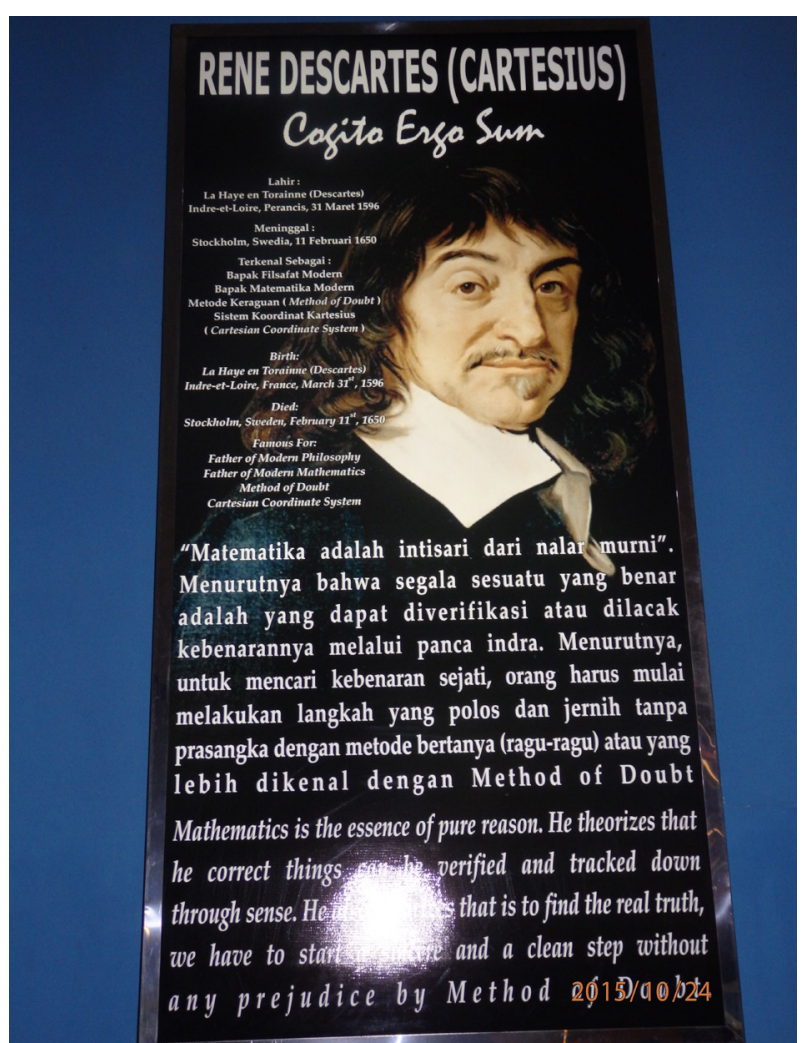

Figure 5. The Illustration Picture of René Descartes in the Main Room of Oval-Kotak Building at Taman Pintar Yogyakarta. (Source: A Photo by Kasiyan) 
find the real truth, we have to start a plain and a clean step without any prejudice by Method of doubt".

Figure 6 shows the figure of Sir Francis Bacon. Underneath his picture, a short note is written saying that Novum Organum. The picture is also completed by a brief biography about the scientist. He was born in York House Strand, London, England on January $22^{\text {nd }} 1561$ and died in St Alban on April 9 ${ }^{\text {th }}, 1626$. There is also an additional note talking about the reason why he became famous. It is written that he is famous for his scientific method. It is followed by a longer explanation about his theory saying that, "Science is not turning point and not taking any conclusion from it, but science is a circle point. People have to observe it to understand the world. First, collect facts, then take the conclusion form the facts by logical inductive argumentation. A kind of method that changes the former science paradigm known as Scientific Method".

Figure 7 shows the figure of Nicolaus Copernicus, and a brief biography about him. It is written that he was born in Tor'un Royal, Prussia, Poland on February 19 ${ }^{\text {th }}, 1473$ and died in Frambork, Wermia, Ermeland, Poland on May 24 ${ }^{\text {th }}, 1543$. He

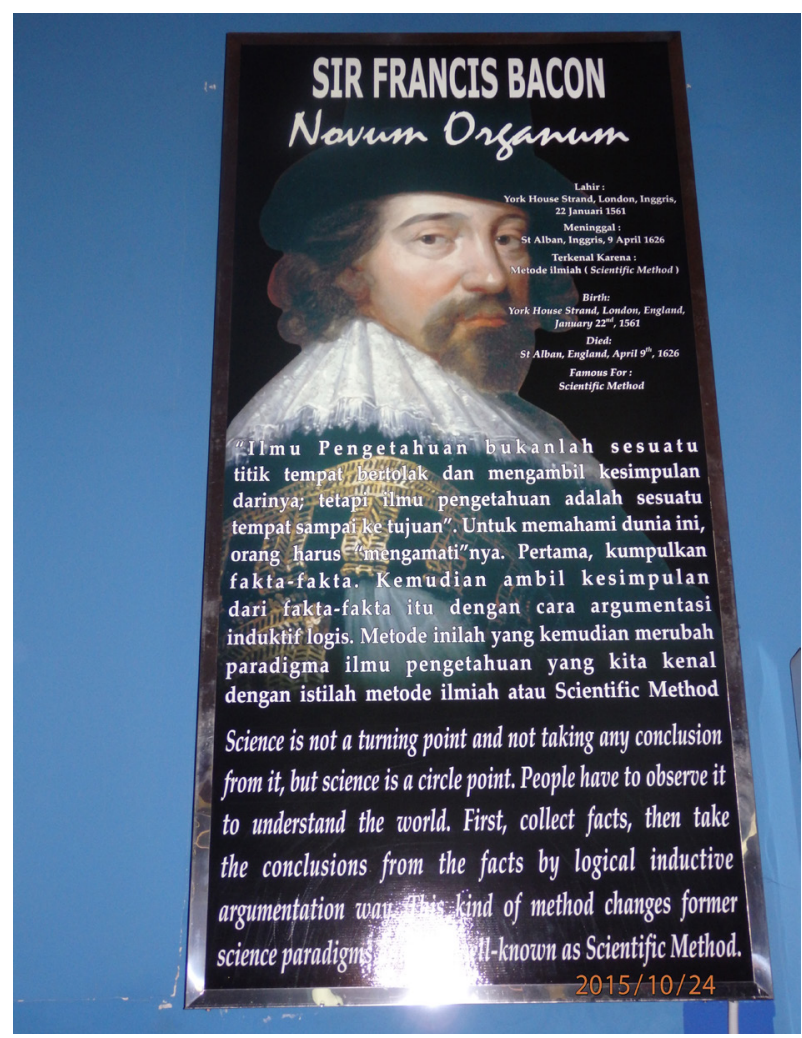

Figure 6. The Illustration Picture of Sir Francis Bacon in the Main Room of Oval-Kotak Building at Taman Pintar Yogyakarta. (Source: A Photo by Kasiyan) is famous for the first modern formulation of the Heliocentric Theory of the Solar System. It is written, "Earth spins of its axis. Moon rotates around the sun and the earth. And the other planets rotate around the sun. Although the calculation is not quite exact in surronding sun planets ratate scale, it has briken the geocentric paradigm (classic comprehension that says the earth is the center of solar system with the heliocentric paradigm. The comprehension that the sun is the center of solar system). The Copernicus theory has renewed our concept about space and also has changed the human race philosophy view point".

Those are the discussions of the display of the illustration pictures found in Taman Pintar Yogyakarta that become one of the focuses of the discussion through out this writing. The underlying reason of the discussion lies on the fact that the use of those illustration pictures portrays a question, a problem. The problem has nothing to do with the existence of those scientists but rather to the representation that shows Western hegemony. The fact that not all of the world great scientists coming from the West and there are plenty of them coming from the East are not discussed. There is

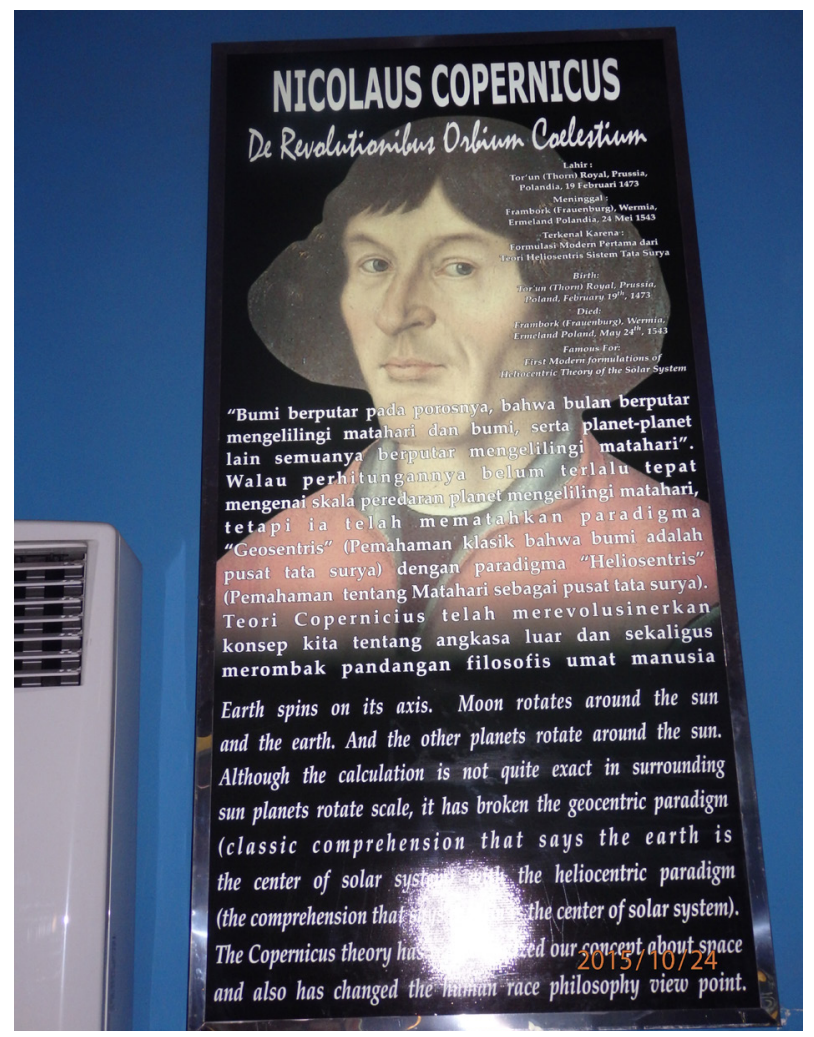

Figure 7. The Illustration Picture of Nicolaus Copernicus in the Main Room of Oval-Kotak Building at Taman Pintar Yogyakarta. (Source: A Photo by Kasiyan) 
not even a single picture showing a scientist from Eastern countries. Although the findings of the Eastern scientist are said to come earlier than the Western ones, but still there is not even a single picture discussing and providing a brief explanation about an Eastern scientist together with his/her short biography as well as his finding theory.

It is very classical that the history of science and culture has not always talked about the truth (Krupat, 2010:74), as it is always related to political constellation and interest to get the power (Carter, Morris, \& Nicholas, 2004:143). Therefore, there are many historical manipulations not to mention the history of science and culture done by the winner as mentioned by Reading (2013) that, "The winners in history usually hide what is inconvenient to them, or manipulate the truth to suit the scale of their ambitions". In the discussion of postcolonial context, the winners are the West and conversely the losers are the East.

Take for instance, the history of printed machine, it is mentioned in almost all of the writing that it came from the West and was found by a German scientist named Gutenberg in 1450s (Gunaratne, 2001; Dittmar, 2015). In fact, the printed technology had been earlier found in the East, particularly in China in the 11 st century or around 450 years before Gutenberg found that, by a scientist named Bi Sheng (990-1051) in the era of Song Dinasty (Teresi, 2005: 123; Hansen, 2010: 341). Then, it is also the case in the invention of historiography and sociology that is considered found by Western scientists called Machiaveli and Comte (Stolley, 2005; Soyer, 2010). In fact it was developed by an Eastern scientist called Ibn Khaldün (Ki-Zerbo, 1990; Alatas, 2010:3) far before that. There is also an Eastern scientist called Ibn Sina who has rarely been mentioned in the Western modern medical history, although his book entitled $A$-Qanun fi-Tibb as mentioned by Sir Rhomas Arnold \& Alfred Guillaume in his book The Legacy of Islam published by Oxford University Press (1952), has been used as the main reference in European universities for more than 700 years up to the $17^{\text {th }}$ century (Nasution, 1992: 197). There are also many Eastern scientists who have great contribution in the advancement of world science and technology but their existence and contribution have been negated.

In Indonesian context, there are also many figures that seem to be having such great contribution and theory as the Western figures. They have proposed authentic ideas and given so many inheritances and masterpieces in the science, culture and arts that spread out throughout the entire country, Indonesia, such as batik, wayang (the leather puppets), gamelan, keris, Borobudur and Prambanan temples, and many others. The masterpieces have been in this country for thousands of years and even nowadays have been not only Indonesian belonging but also have been verified by the United Nations as the world heritage. These masterpieces had been in this country far before it met the Western science and culture. It was in the era of pre-Indonesia known as Nusantara. It is widely known that it was not until the $16^{\text {th }}$ century that Nusantara met the West (Frengs, 2017: 22; Paine, 2014; West, 2010: 944), while the advancements of those masterpieces had occurred thousands years before that.

But once again, it is not considered representative to be considered as a great narration in the civilization that is equal to the West. This phenomenon is a kind of losing the battle in the cultural constellation that is not supposed to be transformed and internalized to young generations that are going to be the next generations of this country in the future.

On the other hand, this phenomenon is a kind of missing link and misfortune that it has never been truly objective even free from values (Eekels, 2007; Liebhafsky, 2016). The same thing happened in arts and aesthetics. They have never been free from values (Vuyk, 2010), as represented by the illustration pictures depicted at Taman Pintar Yogyakarta. Every work of arts and cultural representation needs to cover the importance of finding any possibilities to present values particularly for the sake of their own cultural well being, not to mention in Indonesian contemporary arts (Nugroho \& Himawan, 2014). This construction of thought is the one later called the "aesthetic pedagogy" (Handayani \& Emilda, 2018) or in Dewey's concept (Pugh \& Girod, 2017; 
Light \& Smith, 2005) is called "transformative aesthetic".

\section{Factors Leading to the Strong Hegemony of Postcolonial Aesthetics Represented in Illustration Pictures at Taman Pintar Yogyakarta}

The question of the strong aesthetic hegemony of Western values as represented in illustration pictures at Taman Pintar Yogyakarta, as mentioned earlier is the result of a complex factor.

Looking carefully to the phenomenon, it is clearly seen that this particular discourse has something to do with the postcolonial burden that remains suffered by Indonesian people though this country has proclaimed its independence in 1945. In postcolonial context, the independence of a nation is a statement of de yure dictum that is often difficult to be verified in the de facto level, and what really exists is what is so called pseudoindependence (Kalu \& Falola, 2019: 261; Victor $\&$ Ndi, 2018: 132).

In other words, it can be stated that the postcolonial era is still going on with a different type of colonization process. It is in the form of substance with its persuasive way by means of science rather than physical colonization with its coercive way (Chafer, 2002: 20; Baker \& Saldanha, 2009: 200). But, one thing to be sure that naturally the basic character remains the same. Both the former and the later type of colonization are very destructive. There is always the problem of inequalities. The existence of two opposite sides of the colonized and the colonizer together with all of the unequal dialectic construction between the inferior and superior sides with all of the big narration remains the same.

Therefore, the problem of Western superiority and the Eastern inferiority, not to mention the one that happened in Indonesia, is similar to the typical prototype of colonization that happened in the past during the physical colonization. In the context of this study, this phenomenon can be clearly verified from the illustration pictures found at Taman Pintar Yogyakarta, that all of them show Western scientist figures without accompanying even by a single picture of the one from the Eastern countries including the one from this country, Indonesia. Although there have been adequate historical evidence and facts concerning that phenomenon. It is supposed to be different. There are many scientists from Eastern countries having great findings and theories, not to mention those from Indonesia have the equal capacity as those of the Western. These Eastern scientists have given significant contribution with their best thoughts for the sake of constructing the modern and future science. Looking at the historical evidence and facts, it is not excessive to say that it is the Eastern scientists who put the foundation of sciences before the Western developed them at the end.

Looking back to this phenomenon carefully, it is clearly right that an historian Onghokham (2009: 163) states that the independent statement of Western ex-colonialized nations, such as Indonesia, basically means a statement of separation in terms of physical condition from of its main country, that is the West, that in Javanese term called palihan nagari (scheuring van het rijk), but the whole cultural awareness and structure remains the same as the previous condition, the condition of being colonialized.

\section{Conclusion}

In line with the research findings and discussions provided in the previous sub section, some conclusions could be drawn as the following. First, there is a representation of postcolonial aesthetic hegemony in illustration pictures at Taman Pintar Yogyakarta. This representation is in the form of illustration pictures of world science figures coming from the Western countries. The scientists are Nicolaus Copernicus, Sir Francis Bacon, Rene Descartes, Sir Issac Newton, Albert Einstein, and Stephen William Hawking. Meanwhile, there is not even a single picture showing a picture of an Eastern scientist. In fact, there are many inventions and theories that were found by Eastern scientists. Many historical evidence and facts even have shown that the development of philosophy and science has earlier come into being in the Eastern countries than in the Western ones. This phenomenon is a kind of losing the battle in the cultural constellation that is not supposed to be transformed and internalized 
to young generations that are going to be the next generations of this country in the future.

Second, the factor leading to the representation of the strong construction of Western hegemony in the illustration pictures at Taman Pintar Yogyakarta is mainly related to the postcolonial burden of this country. This country has suffered from this postcolonial burden for a long time in its entire cultural aspects that is represented in the form of various expressions of Western superiority and Eastern inferiority together with its great narration. It is truly a cultural misfortune that imperatively needs to be enlightened immediately. Some strategies need to be applied to get a cultural enlightenment for this country. One of the strategies that can be done is by constructing and developing a critical awareness in every cultural and art work, by means of what is so called "aesthetics pedagogy" or in Dewey's concept is called "transformative aesthetics" or "aesthetics battle".

\section{Acknowledgements}

We would like to thank the editors of the Journal of Urban Society's Arts, ISI Yogyakarta for providing me with moral support throughout the makings of this paper and agreeing to publish my article.

\section{References}

Alatas, S. F. (2010). Bab I: Masalah Utama Ilmu Sosial di Asia: Kritik, Diagnosis, dan Rumusan, in Diskursus Alternatif dalam Ilmu Sosial Asia: Tanggapan terhadap Eurosentrisme. Terjemahan Ali Noer Zaman. Fisrt Printing. Bandung: PT Mizan Publika.

Andisca, D., Harsasto, P., \& Adnan, M. (2016). Analisis Kerjasama Pemerintah Daerah DKI Jakarta dengan Yayasan Dharmaranya Tuju Enam dalam Pembangunan Taman Pintar Pulogadung. Journal of Politic and Government Studies, Vol. 5, No 04.

Atwood, G.E. \& Stolorow, R.D. (2013). Legacies of the Golden Age: A Memoir of a Collaboration. The Humanistic Psychologist, 41:3, 285-300, DOI: 10.1080/08873267.2013.791199.
Aziz, N.A, Ariffin, A.A.M, Omar, N. A., \& Evin, C. (2012). Examining the impact of visitors' emotions and perceived quality towards satisfaction and revisit intention to theme parks. Jurnal Pengurusan, 35, 97-109. https:// ukm.pure.elsevier.com/en/publications/ examining-the-impact-of-visitors-emotionsand-perceived-quality-t.

Bai, B., Cai, L.A. \& Zhang, L. (1999). Gaming: A defacto branch of China's tourism, Asia Pacific Journal of Tourism Research, 4:2, 35-40, DOI: 10.1080/10941669908722042.

Baker, M. \& Saldanha, G. (2009). Routledge Encyclopedia of Translation Studies. London: Routledge.

Belton, B. (2014). Compassion and the Colonial Mentality. Rotterdam: SensePublishers. https://doi.org./10.1007/978-94-6209-7674_5. Online ISBN: 978-94-6209-767-4.

Bryant, L.M. (2011). A Golden Age. The Court Historian, 16:1, 83-89, DOI: 10.1179/ cou.2011.16.1.006.

Caron, G. \& Carr-Hill, R.A. (1991). "Non-formal education: Information and Planning Issues". International Institute for Educational Planning Research Report No. 90. Paris: Unesco.

Carter, A., Morris, G., \& Nicholas, L. (2004). Rethinking Dance History: A Reader. London: Psychology Press.

Chafer, T. (2002). The End of Empire in French West Africa: France's Successful Decolonization. London: Bloomsbury Publishing.

Clendinning, E. (2016). Learning in the "Global Village": Performing Arts Edutourism in Bali, Indonesia. Muscultures, Vol. 43, No. 2, (2016). Retrieved from https://journals.lib. unb.ca/index.php/MC/article/view/25476.

Comfort, K. (2008). Art and Life in Aestheticism: De-Humanizing and Re-Humanizing Art, The Artist, and The Artistic Receptor. London: Palgrave Macmillan.

Croce, B. \& Ainslie, D. (1995). "Chapter XII: The Aesthetic of the Sympathetic and Pseudo-aesthetic Concepts", in Aesthetic as Science of Expression \& General Linguistic. New Brunswick, New Jersey: Transaction Publishers. 
Decena, A.M. (2014). Identity, Colonial Mentality, and Decolonizing the Mind: Exploring Narratives and Examining Mental Health Implications for Filipino Americans. Dissertations. 769. https://scholarworks.smith. edu/theses/769.

Dittmar, J. (2015). New Media, Competition and Growth: European Cities After Gutenberg. This paper as Part of the Centre's Globalisation Programme. London: Centre for Economic Performance, London School of Economics and Political Science.

Durado. L. \& Leite, L. (2013). Field Activities, Science Education and Problem-solving. 4th International Conference on New Horizons in Education. Procedia - Social and Behavioral Sciences, 106 ( 2013 ) 1232-1241. Doi: 10.1016/j.sbspro.2013.12.138.

Eekels, J. (2007). Values, Objectivity and Subjectivity in Science and Engineering. Journal of Engineering Design, 6:3, 173-189, DOI: 10.1080/09544829508907912.

Foster, Hal. (2002). The Anti-Aesthetic: Essays on Postmodern Culture. New York: New Press.

Frengs, J. (2017). Corporeal Archipelagos: Writing the Body in Francophone Oceanian Women's Literature. Lexington: Lexington Books.

Greene, J.P., Kisida, B., \& Daniel, H. (2014). The Educational Value of Field Trips: Taking Students to an Art Museum Improves Critical Thinking Skills, and More. Education Next, Vol. 14, No. 1

Gunaratne, S.A. (2001). Paper, Printing and the Printing Press: A Horizontally Integrative Macrohistory Analysis. International Communication Gazette, Volume: 63 issue: 6, 459-479. DOI: 10.1177/0016549201063006001.

Handayani, W. \& Emilda, N. (2018). Pedagogi Estetik Berbasis Kearifan Lokal melalui Kriya Nusantara Batik Cianjur. Journal of Urban Society's Arts, Vol. 5, No. 2, Oktober 2018, 59-65.

Hansen, V., Curtis, K., \& Curtis, K.R. (2010). Voyages in World History. Volume 1. Wadsworth, Boston, USA: Cengage Learning. Hittleman, D.R. (2012). A Picture is Worth a
Thousand Words... If You Know the Words. Childhood Education, 62:1, 32-36, DOI: 10.1080/00094056.1985.10520218.

Howatson, M.C. (2013). The Oxford Companion to Classical Literature. Oxford: Oxford University Press.

Kalu, K. \& Falola, T. (2019). Exploitation and Misrule in Colonial and Postcolonial Africa. Berlin, Heidelberg: Springer.

Ki-Zerbo. (1990). General History of Africa I: Methodology and African Prehistory. London: James Currey Ltd.

Kodri, F.K.N.A, Indriastjario, \& Dwiyanto, A. (2014). Taman Pintar Purwokerto (Sains Center). Imaji, Vol. 3, no. 3, Juli, 189-198.

Krupat, A. 2010. Red Matters: Native American Studies. Philadelphia, Pennsylvania: University of Pennsylvania Press.

Lapan, S.D., Quartaroli, M.T., \& Riemer, F.J. (2011). Qualitative Research: An Introduction to Methods and Designs. New York: John Wiley $\&$ Sons.

Latchem, C. (2014). Informal Learning and NonFormal Education for Development. The Journal of Learning for Development, Vol. 1, No. 1.

Laverty, S.M. (2003). Hermeneutic Phenomenology and Phenomenology: A Comparison of Historical and Methodological Considerations. International Journal of Qualitative Methods, 2(3), 21-35.

Liebhafsky, E.E. (2016). Value-Free Science? Purity and Power in Modern Knowledge. Journal of Economic, Issues, 26:3, 966-968, DOI: 10.1080/00213624.1992.11505356.

Light, A. \& Smith, J. (2005). The Aesthetics of Everyday Life. New York: Columbia University Press.

Lukas, S.A. (2008). Theme Park. London: Reaktion Books.

Madoff, S.H. (2009). Aesthetes and Anti-Aesthetes. In Art School: (Propositions for the 21 $1^{\text {st }}$ Century). Cambridge: Massachutts Institute of Technology Press.

Magnaye, D.C. (2019). Climate Smart Agriculture Edu-tourism: A Strategy to Sustain Grassroots Pro-biodiversity Entrepreneurship in the Philippines. In Stankov U., Boemi, S.N., 
Attia, S., Kostopoulou, S., Mohareb, N. (eds), Cultural Sustainable Tourism. Advances in Science, Technology \& Innovation (IEREK Interdisciplinary Series for Sustainable.

Martin, D., \& Endangsih, T. (2018). Perancangan Taman Edukasi dengan Pendekatan High Tech di Kembangan Selatan Jakarta Barat. Maestro, 1(2), 92 - 100. Retrieved from http:// jom.ft.budiluhur.ac.id/index.php/maestro/ article/ view/48.

Matahir, H. \& Tang, C.F. (2017). Educational Tourism and Its Implications on Economic Growth in Malaysia. Asia Pacific Journal of Tourism Research, 22:11, 1110-1123, DOI: 10.1080/10941665.2017.1373684.

McCleneghan, B. \& Jackson, K.W. (2019). When Kids Ask Hard Questions: Faith-Filled Responses for Tough Topics. St. Louis, MO: Chalice Press.

Merritt, R., Kline, C., Crawford, A., Viren, P.P. \& Dilworth, G. (2016). An Exploration of Recreational Activities While Travelling Relative to Psychographic Tendencies. Tourism Recreation Research, 41:3, 302-313, https:// doi.org/10.1080/02508281.2016.1199123.

Miles, M.B.A., Huberman, M. \& Saldaña, J. (2013). Qualitative Data Analysis. London: Sage Publication.

Mura, P. \& Tavakoli, R. (2014). Tourism and Social Capital in Malaysia. Current Issues in Tourism, 17:1, 28-45, DOI: 10.1080/13683500.2012.718320.

Nasution, Harun. (1992). Kebudayaan Islam Klasik dan Kebudayaan Indonesia. Kongres Kebudayaan 19991: Warisan Budaya; Penyaringan dan Pemeliharaan, Buku I. Jakarta: Departemen Pendidikan dan Kebudayaan, Direktorat Jenderal Kebudayaan, Direktorat Sejarah dan Nilai Tradisional, Proyek Penelitian Pengkajian dan Pembinaan Nilainilai Budaya.

Novelli, N. \& Burns, P. (2010). Peer-to-Peer Capacity-Building in Tourism: Values and Experiences of Field-Based Education. Development Southern Africa, 27:5, 741-756, DOI: 10.1080/0376835X.2010.522835.

Nugroho, B.A. \& Himawan, W. (2014). Visual Tradisi dalam Karya Seni Lukis Kontemporer
Sebagai Wujud Artistik Pengaruh Sosial Budaya. Journal of Urban Society's Arts, Volume 1, Nomor 4, Oktober, 99-109.

Obrien, P.W. \& Jamnia, M. (2013). International Educational Tourism and Regional Development in Taiwan: A Discussion Paper. Pan-Pacific Management Review, Vo1. 16, No. 2: 163-189.

Odin, S. (2016). Tragic Beauty in Whitehead and Japanese Aesthetics. New York: Lexington Books.

Onghokham. (2009). India yang Dibekukan: Mooi Indië dalam Seni Rupa dan Ilmu Sosial, in Harsya W. Bachtiar, Peter B.R. Carey, dan Onghokham, Raden Saleh: Anak Belanda, Mooi Indie, dan Nasionalisme. Cetakan Pertama. Jakarta: Komunitas Bambu.

Onwuekwe, C. (2012). Trends in Illustration: A Digital Approach to Large Format Illustrations on Igbo Folklore. Mgbakoigba: Journal of African Studies. Vol. 1. July.

Paine, L. (2014). The Sea and Civilization: A Maritime History of the World. London: Atlantic Books Ltd.

Patterson, I. (2017). Tourism and Leisure Behaviour in an Ageing World. Oxfordshire, England: CABI Publishing.

Pengunjung Taman Pintar Tembus 1 Juta Orang. https://jogjapolitan.harianjogja.com/ $\mathrm{read} / 2018 / 12 / 29 / 510 / 961857 /$ pengunjungtaman-pintar-tembus-1-juta-orang.

Priasani, W. (2009). Taman Pintar Wonderia di Semarang. Undergraduate Thesis, Jurusan Arsitektur Fakultas Teknik Undip.

Priyanti, A.D., Suparno, \& Sumaryoto. (2019). Sinergitas Desain Perpustakaan Umum dan Taman Pintar di Surakarta. Senthong: Jurnal Ilmiah Mahasiswa Arsitektur, Vol. 2, No. 1, 41-52.

Pugh, K.J. \& Girod, M. (2017). Science, Art, and Experience: Constructing a Science Pedagogy From Dewey's Aesthetics. Journal of Science Teacher Education, 18:1, 9-27, DOI: 10.1007/ s10972-006-9029-0.

Rafael, V. (2015). The War of Translation: Colonial Education, American English, and Tagalog Slang in the Philippines. The Journal of 
Asian Studies, 74(2), 283-302. https://doi. org./1017/S0021911814002241.

Rahman, S.A, Singgih, E.P., \& Setyaningsih, W. (2016). Arsitektura, Vol. 14, No.2, Oktober. DOI: https://doi.org/10.20961/arst.v14i2. 9080

Reading M. (2013). Nostradamus and the Third Antichrist: Napoleon, Hitler and the One Still to Come. London: Duncan Baird Publishers.

Richard, D.M. (2010). Philosophy Before Socrates: An Introduction With Texts and Commentary. Indianapolis. Indiana: Hackett Publishing Company, Inc.

Ritchie, B.W., Carr, N., \& Cooper, C.P. (2003). Managing Educational Tourism. Bristol, UK: Channel View Publications.

Rochberg, F. (2017). Looking at it from Asia: the Processes that Shaped the Sources of History of Science. Berlin, Germany: Springer Science \& Business Media.

Sacks, D. \& Murray, O. (1995). A Dictionary of the Ancient Greek World. Oxford: Oxford University Press.

Sahakian, W.S. (1963). Systems of Ethics and Value Theory. New York: Philosophical Library.

Said, E.W. (1979). Orientalism. First Published. New York: Vintage Books.

Soyer, M. (2010). Examining the Origins Of Sociology: Continuities and Divergences Between Ibn Khaldun, Giambattista Vico, August Comte, Ludwig Gumplowicz, and Emile Durkheim. Thesis Prepared for the Degree of Master of Science, University of North Texas. Stolley, K.S. (2005). The Basics of Sociology. Westport, CT: Greenwood Press.

Syam, M.N. (2009). Sistem Filsafat Pancasila (Tegak sebagai Sistem Kenegaraan PancasilaUUD Proklamasi 1945). Proceeding Kongres Pancasila: Pancasila dalam Berbagai Perspektif, Yogyakarta, 30 Mei-1 Juni 2009. Jakarta: Sekretariat Jenderal Mahkamah Konstitusi.

Taman Pintar Yogyakarta Dilengkapi Wahana Air. In http://www.tempo.co/read/news/2012/05/ 13/199403585/, Tempo Interaktif, diakses Maret 2019.

Teresi, D. (2005). Lost Discoveries: The Ancient Roots of Modern Science-from the Babylonians to the
Maya. New York: Simon \& Schuster, Inc.

Tesch, R. (2013). Qualitative Research: Analysis Types and Software. London: Routledge.

Thoo, J.B. (1998). A Picture Is Worth a Thousand Words. The College Mathematics Journal, 29:5, 408-411, DOI: 10.1080/07468342.1998.11973977.

Toor, M.L. (1996). The Desktop Designer's Illustration Handbook. Hoboken, New Jersey: John Wiley \& Sons.

Undang-undang Nomor 10 Tahun 2009 tentang Kepariwisataan.

Victor, N. \& Ndi, G.S. (eds). (2018). Re-writing Pasts, Imagining Futures: Critical Explorations of Contemporary African Fiction and Theater. Lakewood, USA: Spears Media Press.

Vuyk, K. (2010). The Arts As An Instrument? Notes on the Controversy Surrounding the Value of Art. International Journal of Cultural Policy, 16:2, 173-183, DOI: 10.1080/10286630903029641.

Wahana Teknologi Informasi Paling Diminati Pengunjung Taman Pintar. Http://jogja. tribunnews.com/2014/07/05/wahanateknologi-informasi-paling-diminatipengunjung-taman-pintar.

West, B.A. (2010). Encyclopedia of the Peoples of Asia and Oceania. New York: Infobase Publishing.

Whewell, D. (2009). Aestheticism. In A Companion to Aesthetics. Second Edition. Chilchester, West Sussex,UK: John Wiley and Sons, Ltd., Publication.

Wong, A. \& Wong, C.S. (2009). Factors Affecting Students' Learning and Satisfaction on Tourism and Hospitality Course-Related Field Trips. Journal of Hospitality \& Tourism Education, 21:1, 25-35. https://doi.org/10.1 080/10963758.2009.10696934.

Yekinni, B.O. \& Yusof, R.N.R. (2015). Influence of Policy Strategies, Instruments, and Malaysians' Attitude on Sustainable Edu-tourist Industry in Malaysia. Journal of Tourism, Hospitality and Sports, Vol.14, 26-34.

Yigitcanlar, T. (2013). "Cultivating the Pedagogy of Experience Through International Field Trips: Beyond the National Context". SAGE Open, April-June 2013: 1-12. https://doi. 
org/10.1177/2158244013489560.

Zepke, N. \& Leach, L. (2006). Improving Learner Outcomes in Lifelong Education: Formal Pedagogies in Non-Formal Learning Contexts? International Journal of Lifelong Education, Volume 25, Issue 5,
(September-October), 507-518. https://doi. org/10.1080/02601370600912089.

Zhang, W. \& Shan, S. (2016). The Theme Park Industry in China: A Research Review. Cogent Social Sciences, 2: 1210718. https://doi.org/1 0.1080/23311886.2016.1210718. 